УДК 004.9+ 528

\author{
Попова Марина Андріївна \\ науковий співробітник \\ НЦ «Мала академія наук України», м. Київ, Україна \\ pma1701@gmail.com
}

Бревус Світлана Миколаївна

керівник секції «ГІС у географії»

КПНЗ «Київська Мала академія наук учнівської молоді», м. Київ, Україна

brevus.lana@gmail.com

\title{
СЕРЕДОВИЩЕ НАВЧАЛЬНО-ДОСЛІДНИЦЬКОЇ ДІЯЛЬНОСТІ УЧНІВ НА ОСНОВІ ПОСДНАННЯ ОНТОЛОГІЧНОГО ІНТЕРФЕЙСУ І ГІС-ТЕХНОЛОГІЙ
}

\begin{abstract}
Анотація. У статті розглядаються питання застосування комп'ютерних онтологій i онтологічного інтерфейсу як ефективного засобу інтеграції, агрегації та візуалізації розподілених інформаційних ресурсів і систем на основі використання семантичних властивостей $з$ метою створення і використання інформаційних середовищ у навчальнодослідницькій діяльності учнів. Описується підхід поєднання можливостей комп'ютерних онтологій i функцій геопросторового аналітичного інструментарію ГІС. Наводиться методика застосування онтологічного інтерфейсу на прикладі створення тематичних шарів карт у ГІС-середовищі на основі тематичної онтології.
\end{abstract}

Ключові слова: онтологія; онтологічний інтерфейс; геоінформаційні системи; електронна карта; Web-додаток електронної карти.

\section{1. ВСТУП}

Освіта і наука нині стають пріоритетними факторами розвитку соціальноекономічного, духовного та політичного життя нашої країни. Згідно указу Президента України № 344/2013 [1] сучасна філософія освіти, оновлена стратегія іiі реформування вимагають принципово нових наукових досліджень, обгрунтованого і послідовного запровадження передових науково-педагогічних технологій, раціональних і ефективних підходів до організації наукової й інноваційної діяльності у сфері освіти. У цих умовах особливого значення набуває проблема інновацій у сфері знань. Нові цілі модернізації освітньої галузі спрямовані на розвиток національної системи освіти, що має відповідати викликам часу і потребам особистості, яка здатна реалізувати себе в суспільстві, що постійно змінюється.

В освітньому просторі України на сьогоднішній день актуальною $є$ проблема підвищення якості позашкільної освіти. Наприклад, одним з інноваційних векторів у діяльності Комунального позашкільного навчального закладу «Київська Мала академія наук учнівської молоді» $є$ впровадження ІКТ в освітній процес відділення «Наук про Землю», а саме використання геоінформаційних систем (ГІС) у підготовці учнями науково-дослідницьких робіт. Оскільки цей напрямок у нашій країні в основному розвивається на рівні вищої освіти, то здобутки Київської МАН можна вважати плацдармом практичного впровадження ГІС у систему як шкільної, так і позашкільної освіти. Однією з найважливіших передумов упровадження геоінформаційних систем у середню освіту $є$ розвиток творчих здібностей учнів. Геоінформаційні системи явище відносно нове. Їх поява — це синтез наук: старих, як світ, географії й картографії і сучасних інформаційних технологій. Висловлювання П. П. Семенова-Тянь-Шанського про те, що «карта важливіше опису, оскільки говорить нерідко набагато яскравіше, наочніше і лаконічніше найкращого тексту», у наш час не тільки не втратило своєї 
актуальності, але стало ще більш точно і яскраво висловлювати багатофункціональність, глибину і масштабність сучасної карти. Завдяки новітнім технологіям карти краще читаються, $є$ більш доступними для розуміння школяра, більшими за обсягами і точнішими, - з'явилася можливість деталізації карт завдяки використанню космічних знімків.

Використання комп'ютерних технологій у процесі навчання географії сприяє зацікавленості і креативності школярів у досліджуваному предметі. Тим більше, що широкомасштабне застосування електронних карт можливе не тільки на уроках географії.

Комп'ютерні технології вносять великі зміни і у традиційну навчальнодослідницьку діяльність як під час створення картографічних матеріалів, так й у використанні і їх аналізі. Основна географічна інформація в даний час міститься в цифровому вигляді у просторових базах даних. Однак доступ до цих ресурсів значно обмежений через їх погану структурованість, недостатню систематизованість і до того ж розподіленість по різних інтернет-сайтах, бібліотеках та архівах.

Для розв'язання цієї проблеми доцільно використовувати поєднання геоінформаційних систем й онтологічного інтерфейсу, яке би забезпечувало систематизацію знань й інформаційних ресурсів необхідної наукової тематики, їх інтеграцію в єдиний інформаційний простір і змістовний доступ до них [2]. Наразі даний підхід природно інтегрує найбільш важливі компоненти технології Semantic Web, зокрема, використання онтології для подання семантики інформаційних ресурсів i підтримки їх інтелектуального аналізу.

Використання у навчанні дослідницьких прийомів і методів із застосуванням ГІС сприяє глибокому засвоєнню учнями знань, формуванню у них умінь і навичок, вихованню інтересу до пізнавальної, творчої діяльності. Учням пропонується долучитись до власного творчого пошуку у відкритті нових знань, спробувати себе в ролі «юного дослідника», доторкнутись до світу серйозної науки і зробити свій перший самостійний крок у невідоме.

Постановка проблеми. Задача ідентифікації, підтримки та управління семантичними зв'язками між просторово-розподіленими об'єктами реального світу, виявлення і створення топологічних структур, їх відображення і створення нових об'єктів, зв'язків, ув'язування нових атрибутів, що можуть бути використані під час аналітичної обробки інформації, може бути розв’язана шляхом поєднання можливостей онтологічного підходу до представлення інформаційних ресурсів із ГІС-технологіями. Такі топологічні структури можуть використовуватися у формуванні інформаційного середовища учня, мережеві інструменти якого забезпечують пошук, формулювання, формування, структурування та подання інформації i повідомлень, 3 яких у подальшому формуються знання.

Отже, задача створення дослідницького інформаційного середовища 3 використанням класифікації, систематизації та візуалізації логіко-ієрархічних зв'язків між поняттями предметної галузі дослідження із залученням геоінформаційних систем як сучасного трансдисциплінарного методу пізнання $є$ актуальною.

Аналіз останніх досліджень і публікацій. У рамках діяльності наукових відділень і секцій Малої академії наук України здійснюється велика кількість учнівських досліджень в найрізноманітніших наукових напрямках. Однак, постає проблема доступу широкого загалу до отриманих результатів i ïx подальшого використання. Важливі й цікаві результати, як теоретичні, так i практичні, які отримують юні дослідники, залишаються зосередженими лише на рівні Малої академії наук. Прогресує процес зосередження знань, які стають доступними вузькому колу слухачів i дійсних членів МАН. Тому постає завдання надання можливості 
використання цих знань більшій кількості зацікавлених учнів, для яких вони призначені.

Розв'язанню цієї проблеми сприяє реалізація підходу, спрямованого на побудову спеціалізованих інформаційних середовищ поєднання можливостей ГІС й онтологій, орієнтованих на роботу з великою кількістю різноманітних інформаційних ресурсів різних напрямів, які нададуть можливості географічної прив'язки і просторового аналізу. Як моделі представлення знань пропонується використання онтологічного інтерфейсу.

Метою статті $є$ висвітлення підходу до формування онтологічного інтерфейсу агрегації, систематизації, покращення структурованості великих обсягів просторово розподіленої інформації, забезпечення їх формалізованого представлення й ефективного пошуку даних у навчально-дослідницькому середовищі з використанням можливостей геопросторового аналізу в середовищі геоінформаційних систем.

\section{2. РЕЗУЛЬТАТИ ДОСЛІДЖЕННЯ}

3 огляду на аналіз сучасних методів і засобів представлення інформаційних ресурсів інтерфейси систем такого типу призначені для функціонування у гетерогенних розподілених інформаційних середовищах і тому базуються на методах штучного інтелекту і парадигмі Semantic Web. Онтологічний інтерфейс має властивості сучасних портальних рішень, тобто комбінує в собі можливості надання доступу користувачам до інформації (Information Portals) й об'єднання користувачів один 3 одним (Collaboration Portals) на основі таких критеріїв як досвід, галузь експертизи, спільні інтереси тощо (Expertise Portals).

Інформаційне навчально-дослідницьке середовище учня може мати ієрархічну або мережеву структуру, тобто складатися з більш спеціалізованих середовищ чи систем, пов'язаних деякими відношеннями, наприклад «загальне - часткове». Оскільки архітектура такого середовища має надавати гнучкості, можливості до розширення функціональності й агрегації розподілених у мережі інформаційних ресурсів, необхідним є створення ергономічного інтерфейсу користувача, що забезпечує Webдоступ до них.

Тому в основі такого інтерфейсу має бути онтологія, яка умовно поділяється на дві частини: перша містить опис структури середовища дослідження учня, друга ресурси, що описують обрану предметну галузь дослідження. Онтологія визначає загальновживані, семантично значущі «понятійні одиниці інформації», якими оперують дослідники.

Онтологічний інтерфейс дозволяє візуалізувати результат процесів інтеграції й агрегації розподілених інформаційних ресурсів у процесі організації взаємодії користувачів у легкодоступній наочній формі. На відміну від інформації, закодованої в алгоритмах, онтологія забезпечує iї уніфіковане і багаторазове використання різними групами юних дослідників, на різних комп'ютерних платформах під час вирішення різних задач.

Онтологічний інтерфейс - засіб зручної взаємодії користувача 3 інформаційною системою, призначений для розв'язання множини задач проблемної ситуації шляхом використання активної онтології [3]. Під активною онтологією розуміємо таку онтологію, у якій множини концептів (понять предметної галузі) i концептуальних відношень максимально повні, а до функцій інтерпретації додаються аксіоми, визначення та обмеження.

Використання геоінформаційних систем надає додаткових можливостей візуалізації даних з географічною прив'язкою і використання численних аналітичних 
інструментів для підвищення рівня засвоєння знань під час навчально-дослідницької діяльності.

\section{3. МЕТОДИКА ЗАСТОСУВАННЯ}

Формування онтологічного інтерфейсу навчально-дослідницького середовища учня включає чотири етапи:

1. Попередній аналіз текстової інформації за тематикою дослідження. Виділення концептів-понять й об'єднання їх за властивостями у відповідні класи.

2. Формування таблиці класів концептів-понять на основі множини семантичних відповідностей між поняттями.

3. Побудова онтологічного графа.

4. Формалізований опис галузі навчально-дослідницької діяльності й візуалізація онтографу у вигляді інтерфейсу [5].

Отже, функціонал інформаційного середовища дослідження на основі онтології надає юним дослідникам, зацікавленим учням чи звичайним користувачам сучасних інформаційних, аналітичних та пошукових сервісів в обраній області знань:

- доступ до великих масивів інформації, розподілених за багатьма різноформатних баз даних;

- фіксація, відображення, аналітична обробка i контроль результатів досліджень за різними напрямками діяльності;

- пошук, групування, вибір й аналіз відповідних даних;

- оперативний зв'язок й обмін документами і повідомленнями каналами комп'ютерного зв'язку;

- організація контролю за використанням документів тощо.

Класи об’єктів онтології в середовищі ГІС відповідають шарам тематичної карти, а самі об'єкти, що входять до відповідного класу, - об'єктам шару [4]. Завдяки об'єднанню різних типів баз даних в онтології дослідження атрибути об'єктів можуть бути представлені не лише у табличному вигляді, а й у текстовому, а також у вигляді гіперпосилань на розподілені в мережі інформаційні ресурси.

Розглянемо як приклад Web-додаток електронної карти, призначеної для розв'язання завдань, пов'язаних $з$ дослідженням і аналізом фактів життя і діяльності Т. Г. Шевченка, з осмисленням і виділенням головних факторів і причин тих чи інших подій, пов'язаних з біографією Кобзаря, а також їх можливих наслідків, вплив творчості на сучасників і майбутні покоління.

На карті, розробленій НЦ «Мала академія наук України» (http://server1.inhost.com.ua/shevchenko), тематичні шари карти:

- Місця перебування Т. Г. Шевченка;

- Музеї;

- Пам'ятники в Україні;

- Пам'ятники за кордоном

відповідають класам понять онтології, а об'єкти, що нанесені на карту і належать до тематичного шару, — поняттям онтології, об'єднаним в класи.

Однак, у Web-додатку електронної карти в легенді карти символи об'єктів (іконки) тематичних шарів залишаються незмінними в рамках одного шару. Отже, дізнатися назву конкретного музею ми можемо лише переглянувши атрибутивну інформацію. Класи онтології мають повний перелік понять, які відповідають назвам об'єктів тематичного шару, і можуть гнучко доповнюватися новими поняттями, зберігаючи наочність сприйняття користувачем взаємозв'язків між елементами. 
Наприклад, усі музеї на карті мають однаковий символ синього прапорця, його назва міститься в атрибутивній таблиці. 3 онтології ми бачимо, що конкретний об'єкт «Казахська державна художня галерея ім. Т. Шевченка» входить до класу музеїв, що відповідає тематичному шару електронної карти.

Опис об'єкта на карті обмежений полями атрибутивної інформації, а сервіс вкладень дозволяє прикріпити лише ту інформацію, що фізично наявна у користувача. Завдяки об'єднанню різних типів баз даних в онтології атрибути об'єктів можуть бути представлені не лише в табличному вигляді, а й у текстовому, а також у вигляді гіперпосилань на розподілені в мережі інформаційні ресурси.

Контекстне сприйняття кожного поняття онтології логічно доповнюється семантично пов'язаною 3 ним інформацією завдяки пошуковій машині, вбудованій в онтологію, а відображення відповідного поняття як об'єкта тематичного шару у Webдодатку електронної карти дозволяє побачити загальну картину, охоплюючи категорії часу і географічної прив'язки. Наприклад, клас «Місця перебування Т. Г. Шевченка» включає поняття «Санкт-Петербург». За допомогою пошукової машини дізнаємося, що в 1842 році (час) Шевченко, перебуваючи у Санкт-Петербурзі (географічна прив'язка), створив картину «Катерина».

Те ж саме поняття «Санкт-Петербург» входить до класу «Музеї», адже 9 березня 1964 року в Петербурзі у приміщенні Академії мистецтв на Університетській набережній був відкритий Музей-квартира Т. Г. Шевченка.

Як бачимо з карти сучасний Форт-Шевченко (Казахстан, Мангістауська область, Тупкараганський район, Форт-Шевченко) об'єднує у своєму складі одразу кілька понять, пов’язаних 3 життям і творчістю Кобзаря. Поняття онтології «Ніколаєвська», «Уральське укріплення» та «Новопертовське укріплення», що входять до класу «Місця перебування Т. Г. Шевченка», є об' єктами однойменного тематичного шару карти і на даний час входять до складу Форту-Шевченко. Так само Форт-Шевченко є місцем розташування об'єкта тематичного шару «Музеї» «Меморіальний комплекс» й об' єктом тематичного шару «Пам'ятники за кордоном» «Погруддя Т. Г. Шевченка». У період десятирічного заслання і перебування у Форті-Шевченко митцем були створені малюнки, ескізи й нариси «Сад біля Новопетровського укріплення». Зображений на цих роботах сад почали висаджувати біля укріплення в 1853 році за наказом коменданта Ускова. Зведена в саду альтанка, призначена для відпочинку родини коменданта, була сховищем творів Шевченка і місцем, де він малював.

Відображення класів онтології у вигляді тематичних шарів карти дозволяє об'єднати поняття місця і часу 3 поняттями фактів і подій у невідомій до цього комбінації, під новим кутом зору.

\section{4. ВИСНОВКИ ТА ПЕРСПЕКТИВИ ПОДАЛЬШИХ ДОСЛІДЖЕНЬ}

Агрегація онтології і тематичної карти дозволяє розширювати і доповнювати інформаційні описи понять-об'єктів на основі мережевих інформаційних ресурсів, розподілених в Internet, а вбудована в онтологію пошукова машина дає можливість кожному користувачеві виявляти принципово нові, раніше невідомі взаємозв'язки, сприяє зміщенню акцентів із пасивних методів пошуку, орієнтованих на передавання інформації, до ширшого застосування активних методів аналізу проблем, значно розширити уявлення про предметні області і міждисциплінарні зв'язки між ними. Таке поєднання дозволяє створити єдине інформаційне навчально-дослідницьке середовище учня, яке перманентно поповнюється доробками територіально розподілених користувачів різних напрямків досліджень. 
Такий підхід до розв'язку проблеми вибору виходить із природної здатності людей думати логічно й творчо, визначати події й встановлювати відношення між ними. Відзначимо, що людині властиві дві характерні ознаки аналітичного мислення: перша - уміння спостерігати й аналізувати спостереження; інша — здатність встановлювати відношення між спостереженнями, оцінюючи рівень взаємозв'язків між відношеннями, а потім - синтезувати їх в загальне сприйняття спостережуваного.

Використання ГІС-технологій в процесі освіти забезпечується їх популяризацією в мережі Інтернет, запровадженням курсу вивчення ГІС у шкільних (профільна програма 11 класу) й університетських програмах. Проекти, що дозволяють створювати ГIC, вражають багатоманітністю і багатогранністю: від пошуку оптимального рішення щодо розташування організації чи підприємства до планування розвитку міста.

Створення секції «ГІС у географії» у відділені наук про Землю — вагомий крок у напрямку освіти молодої еліти Києва сучасним світовим надбанням у сфері комп'ютеризації географічної освіти. Оскільки навчальна база даного курсу для шкільної освіти практично відсутня у нашій країні, то першочерговим постало питання створення навчально-методичного комплексу. У руслі цього питання у 2013 році спеціалістами відділу впровадження інформаційних та інноваційних технологій КПНЗ «КМАНУМ», інженерів ПрАТ «Есот Со» і науковими співробітниками НЦ «МАНУ» розроблено навчальну програму і навчально-методичний посібник «Основи створення електронних карт на базі програмного забезпечення ArcGIS 10.1» 3 електронною підтримкою курсу до нього.

Навчально-методичний посібник знайомить читачів 3 історією створення i розвитку світової географічної інформаційної системи, іiї структурою, функціями i застосуванням; 3 компонентами програмного забезпечення ArcGIS 10.1 i ïx використанням у створенні електронних карт. У посібнику також подається практичний курс створення електронних карт на основі вказаного програмного забезпечення.

Учні секції, які оволоділи основами геоінформаційних систем, практично застосовують свої знання шляхом наповнення онтологій і електронних карт у процесі навчально-дослідницької діяльності 3 метою відображення сучасного стану нашої країни.

\section{СПИСОК ВИКОРИСТАНИХ ДЖЕРЕЛ}

1. Наказ Президента України № 344/2013 «Про Національну стратегію розвитку освіти в Україні на період до 2021 року» від 25.06.2013.

2. Начало работы с ArcGIS [Електронний ресурс]. - Режим доступу : http://resources.arcgis.com/ru/help/getting-started/.

3. Попова М. А. Модель онтологічного інтерфейсу агрегації розподілених інформаційних ресурсів в галузі екологічної безпеки з використанням ГІС : Екологічна безпека та природокористування : зб. наук. праць / Попова М. А. // М-во освіти і науки України, Київ. нац. ун-т буд-ва і архіт., НАН України, Ін-т телекомунікацій і глобал. інформ. простору; редкол.: О. С. Волошкіна, О. М. Трофимчук (голов. ред.) [та ін.]. - К., 2013. — Вип. 13. - С. 135-143 : іл. — Бібліогр. в кінці ст.

4. Попова М. А. Онтологічний інтерфейс як засіб представлення інформаційних ресурсів в ГІСсередовищі / М. А. Попова, О. Є. Стрижак // Ученые записки Таврического национального университета имени В. И. Вернадского. Серия: География. — 2013. — Т. 26 (65). — № 1. — С. $127-135$.

5. Стрижак О. Є. Засоби онтологічної інтеграції і супроводу розподілених просторових та семантичних інформаційних ресурсів // Екологічна безпека та природокористування : зб. наук. праць / М-во освіти і науки України, Київ. нац. ун-т буд-ва і архіт., НАН України, Ін-т телекомунікацій і глобал. інформ. простору; редкол.: О. С. Волошкіна, О. М. Трофимчук (голов. ред.) [та ін.]. — К., 2013. — Вип. 12. — 198 с. : іл. — Бібліогр. в кінці ст. 


\title{
СРЕДА УЧЕБНО-ИССЛЕДОВАТЕЛЬСКОЙ ДЕЯТЕЛЬНОСТИ УЧАЩИХСЯ НА ОСНОВЕ ОБЪЕДИНЕНИЯ ОНТОЛОГИЧЕСКОГО ИНТЕРФЕЙСА И ГИС- ТЕХНОЛОГИЙ
}

\author{
Попова Марина Андреевна \\ научный сотрудник \\ НЦ «Малая академия наук Украины», г. Киев, Украина \\ pma1701@gmail.com
}

Бревус Светлана Николаевна

руководитель секции «ГИС в географии»

КВУЗ «Киевская Малая академия наук ученической молодёжи», г. Киев, Украина

brevus.lana@gmail.com

\begin{abstract}
Аннотация. В статье рассматриваются вопросы применения компьютерных онтологий и онтологического интерфейса как эффективного средства интеграции, агрегации и визуализации распределенных информационных ресурсов и систем на основе использования семантических свойств с целью создания и использования информационных сред в учебно-исследовательской деятельности учащихся. Описывается подход объединения возможностей компьютерных онтологий и функций геопространственного аналитического инструментария ГИС. Приводится методика применения онтологического интерфейса на примере создания тематических слоев карт в ГИС-среде на основе тематической онтологии.
\end{abstract}

Ключевые слова: онтология; онтологический интерфейс; геоинформационные системы; электронная карта; Web-приложение электронной карты.

\section{THE SPACE OF EDUCATIONAL RESEARCH ACTIVITY OF STUDENTS BASED ON ASSOCIATION ONTOLOGICALLY INTERFACE AND GIS-TECHNOLOGIES}

\author{
Maryna A. Popova \\ researcher \\ SC "Minor Academy of Sciences of Ukraine", Kyiv, Ukraine \\ pma1701@gmail.com
}

Svitlana M. Brevus

head of the section "GIS in geography"

Kyiv Minor Academy of Sciences of School Youth, Kyiv, Ukraine

brevus.lana@gmail.com

\begin{abstract}
This article discusses the ontologies and ontological computer interface use as an effective means of integration, aggregation and visualization of distributed information resources and systems through the use of semantic properties to create and use of information space in education and research activities of students. The approach of combining ontologies features and geospatial analytical tools functions of GIS is described. The technique of ontological interface applying by creating a thematic map layers in GIS environment based on thematic ontology is presented.
\end{abstract}

Keywords: ontology; ontological interface; geographic information systems; e-maps; webapplication electronic map.

\section{REFERENCES (TRANSLATED AND TRANSLITERATED)}

1. Order of the President of Ukraine № 344/2013 "About the National Strategy for the Development of Education in Ukraine for the period till 2021" on 06/25/2013. (in Ukrainian) 
2. Started with ArcGIS [online]. — Available from : http://resources.arcgis.com/ru/help/getting-started/ (in Russian)

3. Popova M. Ontological interface model of distributed information resources aggregation in the environmental safety using GIS : Environmental Safety and Natural resource management: Collection of scientific works / Popova M. // Ministry of Education and Science of Ukraine, Kyiv National University of Construction and Architecture, NAS of Ukraine, Institute of Telecommunication and Global Information Space. - K., 2013. — Vol. 13. - P. 135-143. (in Ukrainian)

4. Popova M. Ontological interface as a means of presenting information resources in the GIS / M. Popova, O. Stryzhak // Scientific Notes of Taurida National V. I. Vernadsky University. — Series : Physics and Mathematics Sciences. - 2013. - Vol. 26 (65). - No. 1 - P. 127-135. (in Ukrainian)

5. Stryzhak O. Means of ontological integration and support of distributed spatial and semantic information resources: Environmental Safety and Natural resource management: Collection of scientific works / O. Stryzhak // Ministry of Education and Science of Ukraine, Kyiv National University of Construction and Architecture, NAS of Ukraine, Institute of Telecommunication and Global Information Space. - K., 2013. - Vol. 12. — P. 168-176. (in Ukrainian) 